\title{
Quantifying intra-annual dynamics of carbon sequestration in the forming wood: a novel histologic approach
}

\author{
Anjy N. Andrianantenaina ${ }^{1}$ (I) $\cdot$ Cyrille B. K. Rathgeber ${ }^{1} \cdot$ Gonzalo Pérez-de-Lis $^{1} \cdot$ Henri Cuny $^{2} \cdot$ Julien Ruelle $^{1}$
}

Received: 26 October 2018 / Accepted: 6 May 2019 / Published online: 17 June 2019

(C) INRA and Springer-Verlag France SAS, part of Springer Nature 2019

\begin{abstract}
- Key message This study presents a novel histologic approach to quantify the intra-annual dynamics of carbon sequestration in forming wood. This innovative approach, based on repeated measurements of xylem apparent density, is more direct, and more accurate than the previously published cellular-based approach. Moreover, this new approach, which was tested here on softwoods, is also applicable to hardwoods without any modification.

- Context Forest ecosystems are key players of the terrestrial carbon cycle. Indeed, wood represents the principal carbon pool of terrestrial biomass, accumulated in trees through cambial activity.

- Aims Here, we present a novel, simple, and fast approach to accurately estimate the intra-annual dynamics of aboveground woody biomass production based on image analysis of forming xylem sections.

- Methods During the 2015 growing season, we weekly collected wood samples (microcores) containing the forming xylem on seven Norway spruces (Picea abies (L.) Karst), grown in Hesse forest (North-East France). The microcores were prepared to allow the observation of the forming tissues with an optical microscope. Xylem apparent density and radial increment were then measured directly on images of the histological sections. In order to compare our "histologic approach" with the previously published "cellular approach," we also counted the number of tracheids in each differentiation zones, and measured the tracheid dimensions all along the last-formed tree ring.

- Results The two approaches yielded comparable meaningful results, describing xylem size increase and aboveground woody biomass production as bell-shaped curves culminating in May and June respectively. However, the histologic approach provided a shorter time lag between xylem size increase and biomass production than the cellular one.

- Conclusion Better quantification of the shift between stem growth in size and in biomass will require addressing the knowledge gap regarding lignin deposition kinetics. Nevertheless, our novel histologic approach is simpler and more direct than the cellular one, and may open the way to a first quantification of intra-annual dynamics of woody biomass production in angiosperms, where the cellular approach is hardly applicable.
\end{abstract}

\section{Handling Editor: Patrick Fonti}

This article is part of the topical collection on Wood formation and tree adaptation to climate

Electronic supplementary material The online version of this article (https://doi.org/10.1007/s13595-019-0846-7) contains supplementary material, which is available to authorized users.

Anjy N. Andrianantenaina anjynandrianina@gmail.com

Cyrille B. K. Rathgeber cyrille.rathgeber@inra.fr

Gonzalo Pérez-de-Lis gonzalo.perezdelis@inra.fr

Henri Cuny

henri.cuny@ign.fr
Julien Ruelle

julien.ruelle@inra.fr

1 Université de Lorraine, AgroParisTech, INRA, UMR Silva, 54000 Nancy, France

IGN, Direction Inter-Régionale Nord-Est, 54250 Champigneulles, France 
Keywords Xylogenesis $\cdot$ Cambial activity $\cdot$ Wood density $\cdot$ Carbon sequestration $\cdot$ Norway spruce $\cdot$ Image analysis

\section{Introduction}

Forest ecosystems constitute important carbon stocks and play a central role in the global carbon cycle (Bonan 2008; Popkin 2015). The main aboveground carbon sink, easily measurable, and quantifiable in trees are the stem and branches which account for around 50 to $60 \%$ of trees total biomass (Kraenzel et al. 2003; Seo et al. 2012). To accurately estimate the aboveground woody biomass produced by trees, it is essential to consider both the stem radial growth and the wood density. Both radial increment and wood density vary between species, based on heritable characteristics (Chave et al. 2006; Nabais et al. 2018; Lundqvist et al. 2018), between years (Bouriaud et al. 2015; Björklund et al. 2017), according to climate conditions (Thomas et al. 2004; Rathgeber 2017; Björklund et al. 2017), but also within a year from early- to late-wood (Vaganov et al. 2006; Cuny et al. 2014). Taking into account seasonal changes in forming xylem density is crucial for an accurate quantification of the seasonal dynamics of aboveground woody biomass production (Heid et al. 2018). But studies at seasonal scale remain rare, which limits our understanding of how internal and environmental conditions drive the processes of tree growth, and their capacity to sequester carbon in the context of climate change.

Xylogenesis, which is the process ensuring wood formation, entails inner mechanisms which modulate at fine scale the production of new cells (increasing stem size), and the carbon deposition within the wall of these newly formed cells (increasing stem biomass). In temperate forests, when favorable conditions resume in spring, xylogenesis manifests with the onset of cambial division. Differentiation of newly produced cambial cells at the inner side forms the xylem, which is basically constituted by tracheids in conifers. Tracheid differentiation starts with the onset of radial expansion, so called the enlarging phase, characterized by a large increase in cell radial diameter and the extension of the thin primary cellulose cell wall. When an enlarging tracheid reaches its final size, it starts to form a thick and lignified secondary cell wall, during the thickening phase (Donaldson 2001; Baucher et al. 2001). The lignin deposition occurs after that of cellulose in secondary wall, and can continue long after the thickening of the secondary wall has been completed (Kagawa et al. 2005). When lignification and secondary wall formation are finished, tracheids undergo programmed cell death to become fully functional (Rathgeber et al. 2016). Cambial cell division and enlargement of the newly produced xylem cells mainly ensure stem radial growth, while cell wall deposition and lignification mainly ensure carbon sequestration in stem woody biomass (Cuny et al. 2015).
Recently, high-resolution cellular-based measurements have improved our understanding of intra-annual dynamics of woody biomass production (Cuny et al. 2015). This approach (hereafter called the cellular approach) is based on counting the number of tracheids in the four differentiation stages, to compute cell differentiation kinetics (timings, duration and rate). It requires measuring mature cell dimensions (e.g., cell radial width, wall radial width, wall cross area, lumen area), applicable to conifers, thanks to the homogeneity of their xylem, which is mainly composed of tracheids (ca. $90 \%$ ). However this approach, in addition of being data intensive and time-consuming, cannot be applied to angiosperms, which show a more complex anatomical structure characterized by a diversity of cell types (e.g., fibers, vessels, rays).

To overcome the limits of the cellular approach, we developed a novel histologic approach based on repeated measurements of xylem radial increment (XRI) and xylem apparent density (XAD) on numerical images of anatomical section of the developing xylem. The two approaches were tested on the same wood samples containing phloem, cambial zone, and developing xylem collected weekly during the 2015 growing season on seven dominant Norway spruce trees (Picea abies (L.) Karst) at the Hesse forest (northeastern France). To compare results obtained with the two histologic and cellular approaches, we (1) computed the differences between each daily estimated values of stem radial growth and AWP, and (2) tested significant differences between estimated tree ring width and total AWP at the end of the growing season.

\section{Materials and methods}

\subsection{Study site}

The Hesse site is located in north-east of France $\left(48^{\circ} 40^{\prime} \mathrm{N}, 7^{\circ}\right.$ $04 \mathrm{E}$, alt. $300 \mathrm{~m}$ ). The forest is managed jointly by the French Forest Service (ONF) and the French National Institute for Agricultural Research (INRA). This forest originates from natural regeneration but was frequently thinned (in 1995, 1999, 2004, and 2015). The slope is gentle (approximately $3 \%$ ), while the soil type ranges between a luvisol and a stagnic luvisol with a $160 \mathrm{~cm}$ depth. The stand is composed mainly of beech (Fagus sylvatica L., around 90\%), accompanied by sessile oaks (Quercus petraea (Mattuschka) Liebl.), hornbeam (Carpinus betulus L.), and in a narrower area by planted Norway spruce trees (Picea abies L. Karst). There is a high canopy closure and sparse understory vegetation. During the year 2015, the mean annual temperature was $10.9{ }^{\circ} \mathrm{C}$ and the total annual precipitation was $687 \mathrm{~mm}$ (Table 1). The 2015 growing season was characterized by a long period of water stress. The dry period 
Table 1 Characteristics of the 2015 growing season at Hesse forest. Annual environmental factors: precipitation, air temperature, duration, and intensity of drought

\begin{tabular}{ll}
\hline Annual precipitation & $687 \mathrm{~mm}$ \\
Mean temperature & $10.9{ }^{\circ} \mathrm{C}$ \\
Duration of drought $(\mathrm{REW}<40 \%)$ & 127 days: from DOY 194 to 323 \\
$\begin{array}{l}\text { Intensity of drought } \\
\quad \text { or water-stress index }\end{array}$ & 38.9 \\
\hline
\end{tabular}

lasted up to 127 days, with daily soil relative extractable water (REW) dropping below the 40\% threshold (Granier et al. 1999) from mid-July to mid-November (Method S1).

\subsection{Sampling and sample preparation}

We selected seven dominant and healthy spruce trees, without any sign of injury (Table 2). Wood samples (microcores) of $2 \mathrm{~mm}$ in diameter by $15-20 \mathrm{~mm}$ in length were collected weekly from March to November 2015 on the stems of the selected trees using a Trephor ${ }^{\circledR}$ tool and following an ascendant spiral starting at breast height (Rossi et al. 2006). Microcores collected on the field were stored in the laboratory in ethanol solution $\left(50 \%\right.$ in water) at $5{ }^{\circ} \mathrm{C}$. Each microcore was oriented under a stereomicroscope, marking the wood grain direction. Microcores were then dehydrated in successive baths of alcohol and Histoclear@, before being embedded in paraffin (Harroué et al. 2011). Finally, transverse sections of $5 \mu \mathrm{m}$ were cut using a rotary microtome, stained with FASGA, and permanently mounted on glass slides using Histolaque LMR®. FASGA combines blue alcian and Safranin dyes (Tolivia and Tolivia 1987), which respectively stain cellulose in blue and lignin in pink.

\subsection{Microscopic observation of xylem cell differentiation}

Overall, 260 anatomical sections were observed using an optical microscope (AxioImagerM2; Carl Zeiss SAS), under

Table 2 Circumference $(\mathrm{CBH}, \mathrm{cm})$ and age (years in 2015) at breast height for the seven studied trees, and mean \pm standard error (se)

\begin{tabular}{llll}
\hline Tree no & Age (years) & CBH $(\mathrm{cm})$ & $\mathrm{H}(\mathrm{m})$ \\
\hline 1 & 36 & 102,6 & 21,60 \\
2 & 37 & 67,0 & 21,50 \\
3 & 33 & 83,5 & 23,30 \\
4 & 39 & 83,7 & 23,70 \\
5 & 37 & 100,3 & 24,00 \\
6 & 34 & 79,1 & 23,40 \\
7 & 37 & 111,7 & 24,30 \\
Mean \pm se & $36.14 \pm 0.77$ & $89.7 \pm 5.91$ & $23.11 \pm 0.42$ \\
\hline
\end{tabular}

visible and polarized light at $\times 100-\times 400$ magnification to distinguish cells in the successive differentiation zones. The cambial zone was composed of thin, flattened, and thin-walled cells. The enlargement zone was composed of large, but still thin walled cells. The cambial and enlargement zones were associated with a uniform blue color, since cell wall was only composed of cellulose. The wall-thickening zone was composed of cells, which present already their mature sizes and shapes while exhibiting birefringent (Abe et al. 1997) and bicolored cell walls (with pink color outward on lignified wall, and blue inward on non-lignified wall). Mature xylem cells also exhibited birefringent walls under polarized light, but associated with a uniform pinkish color in bright field, since their walls were fully lignified.

\subsection{Cellular approach to construct the intra-annual dynamics of growth in size and in biomass}

For each sample, the radial number of cells in the cambial, enlargement, wall-thickening, and mature zones was counted along three radial files. Then, cell counting dataset was processed to characterize the kinetics of tracheid differentiation (Cuny et al. 2013). This approach consists of computing timings (date of entrance into enlargement, wall-thickening and mature zone for each cell), differentiation durations (duration of enlargement and wall-thickening phases), and differentiation rates (cell production, cell enlargement, wall thickening) for all the cells within the ring.

At the end of the growing season, on the entirely formed mature xylem ring, tracheidograms were performed on three radial files to measure the cell radial diameter and the wall cross-sectional area for each cell in each radial file (WinCELL ${ }^{\mathrm{TM}}$ 2016a, Regent Instruments). Then measurements were standardized (Vaganov 1990) and a mean radial file per tree was computed.

Daily xylem size increase and AWP were estimated, based on the contribution of each differentiating tracheid to the radial increase and wall deposition along a radial file (Cuny et al. 2015). The average rates of radial enlargement and wall deposition were computed for each cell by dividing its final dimensions by the duration of the enlargement and wall-thickening phases respectively. Processes were assumed to be evenly distributed along time, considering the same daily rate of respectively radial expansion and wall deposition, throughout the entire period of respectively, cell enlargement and wallthickening phases for each tracheid. To compute the xylem size increase, we added the contribution of cell production due to cambial division, and the contribution of enlarging xylem cells. To compute AWP, we took into account the contribution of cambial division, cell enlargement, and wallthickening cells (see Cuny et al. (2015) and Methods S3-S4 for more details on the cellular approach). Second, we computed the total cell wall area in the stem transverse section by 
multiplying the computed cell wall area in one radial file with the number of radial files for each tree (equal to stem circumference divided by the mean radial width of a radial file). Finally, the cell wall cross-sectional area was converted into AWP per tree, based on the cell wall density: $\rho=1509 \mathrm{~kg} \mathrm{~m}^{-3}$ for Norway spruce (Barnett and Jeronimidis 2009), multiplied by tree height and a stem form coefficient (Fi) based on each tree height and circumference (Vallet et al. 2006).

\subsection{Assessing intra-annual dynamics of XRI and AWP with the histologic approach}

The histologic approach is more direct, considering only two main variables and trees characteristics (height, circumference, Method S4). It is based on repeated measurements of xylem apparent density (XAD), and radial increment (XRI) of the forming xylem (https://doi.org/10.15454/PINS1H). Both $\mathrm{XAD}$ and XRI were used with tree height and circumference to estimate AWP. XAD expressed at a sampling date $t$, the ratio mass to volume of xylem, filled with cell-wall materials, and expressed in $\mathrm{kg}$ per $\mathrm{m}^{3}$ of xylem tissue. To measure XAD, images of developing xylem were acquired for all the anatomical sections using Archimed Software (Microvision Instruments, France) with a digital camera (Sony XCDU100CR) mounted on an optical microscope (AxioImagerM2; Carl Zeiss SAS), under similar lighting and magnification $(\times 200)$. Images were analyzed with ImageJ software (version 1.49v; Abramoff et al. 2004) to estimate the wall proportion in the region of interest, from the boundary between the cambial zone and the phloem cells, to the boundary between the current year xylem and the previous ring. The cellular content was not completely erased for living tracheids, after automatic image processing (Fig. 1), which could affect the measured apparent density (estimated differences of less than 5\%). Presence of rays may also affect the measured apparent density, as reported for spruce, beech, and ash (Sachsse 1984). Since delimitation of the region of interest is crucial, we fixed a tangential width of about $500 \mu \mathrm{m}$ to include three rays for all samples (Fig. 1, Fig. S1). Digital images were converted into grayscale and binarized - all pixels below the mean gray value determined by the thresholding process were considered as matter (cell wall), while those above this value were considered as void (cell lumen). Then, we measured cell wall proportion (\%) and the area of the region of interest (in $\mu \mathrm{m}^{2}$ ). XAD was computed from the product of measured cell wall proportion and the estimated cell wall density $(\rho=$ $1509 \mathrm{~kg} \mathrm{~m}^{-3}$, Barnett and Jeronimidis 2009). Finally, the weekly raw XAD data were fitted for each tree using generalized additive models (Wood 2006).

To measure XRI, we first set the anatomical criteria to identify resting and dividing cambial zone (Annex 1 and table in Annex 2). The radial increment was set to zero when cambial division had not started yet, assuming no contribution

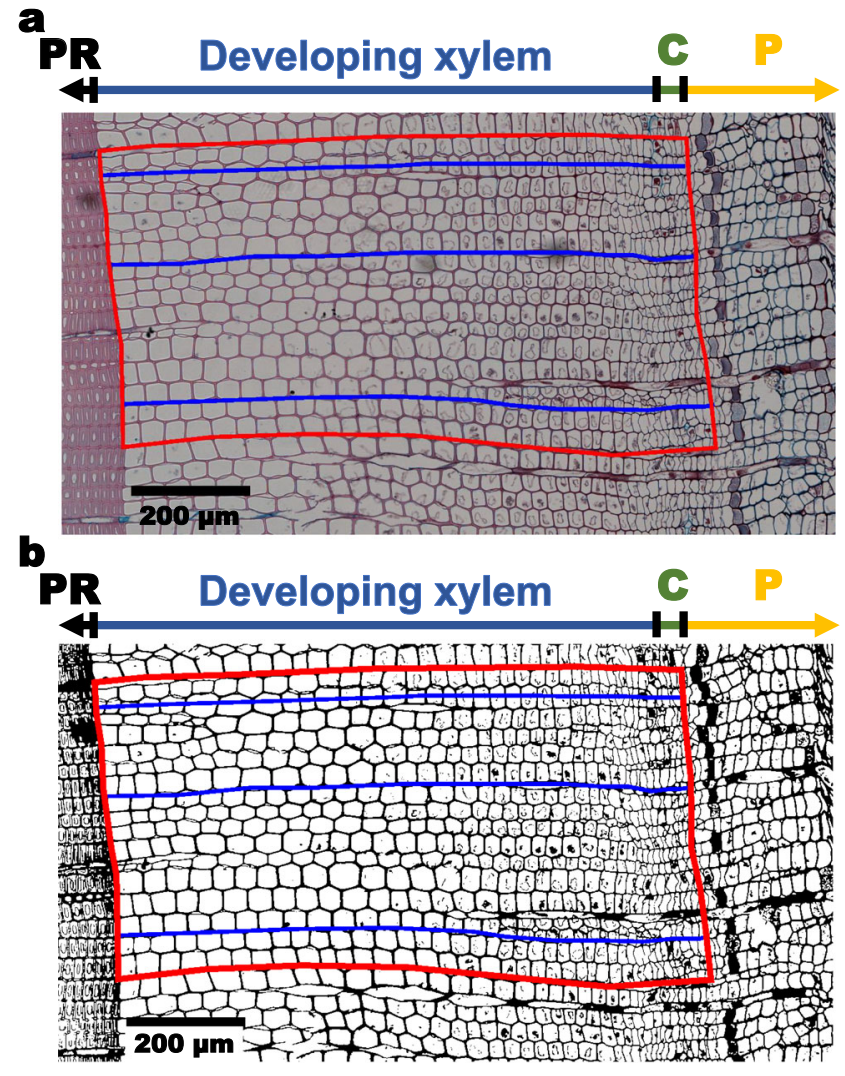

Fig. 1 Illustration of the different variables measured with the histologic approach. Delimitation of the different areas of interest on the processed image with ImageJ: the area of cell wall proportion measurement (red polygon), and the radial increment measurements on three radial files (blue lines) on the image. With P, phloem; C, Cambium, PR, ring of the previous year. The image represents the sample for Tree no 2 sampled on 9th of June 2015 with the original image a and the same image after grayscale and thresholding processing $\mathbf{b}$

of the resting cambium to the stem radius on first samples on March-early April. Then, we measured XRI along three radial file on histological sections, from the boundary between the dividing cambial zone and the phloem cells, to the boundary between the current year xylem and the previous ring. We used the first derivative of cumulated XRI to compute daily XRI $\left(\mu \mathrm{m} \mathrm{day}^{-1}\right)$. AWP was computed at the tree level from the combined time series of volume increase, based on initial tree circumference and height, XRI and XAD. Finally, a SCAM (shape constrained additive models, Pya and Wood 2015) was applied on raw data to assess the seasonal dynamic of cumulative AWP. The following allometry equation (Annex 3) was applied.

$\operatorname{AWP}(t)=F_{i} \cdot H_{i} \cdot \operatorname{XAD}(t) \cdot C C \cdot \frac{\left(C B H_{i}+2 \pi \cdot \mathrm{XRI}(t)\right)^{2}-\left(\mathrm{CBH}_{i}\right)^{2}}{4000 \cdot \pi}$

Where AWP $(t)$ is aboveground woody biomass production $\left(\mathrm{gC}\right.$. tree $\left.^{-1}\right), F_{i}$ is the stem form coefficient (Method S5) used also in cellular approach (Vallet et al. 2006), $H_{i}$ is tree height (m), and $\mathrm{CBH}_{i}$ the circumference at breast height $(\mathrm{cm})$. XAD 
$(t)$ is seasonal variation of xylem apparent density $\left(\mathrm{g} \cdot \mathrm{m}^{-3}\right)$, $\mathrm{XRI}(t)$ is seasonal xylem radial increment $(\mathrm{cm}), \mathrm{CC}$ is carbon proportion in cell wall (fixed to 0.5, Lamlom and Savidge 2003). The list of all variables used in this study is available in Supplementary materials (Table S1).

\section{Results}

\subsection{Spruce wood formation during the $\mathbf{2 0 1 5}$ growing season}

Cambial divisions started in early April, and new produced cells accumulated in the cambial zone for 1 to 3 weeks. Then, first enlarging xylem cells were observed in late April (DOY $114 \pm 0.9$ days, Table S2), marking the first signs of growth after winter for spruce (Fig. 2, Fig. S2). First wall-thickening cells were observed in early May (DOY $129 \pm 2.6$ days), marking the start of significant carbon deposition into the forming xylem. First mature tracheids were observed in early June (DOY $154 \pm$ 2.1 days). Cessation of cambial division occurred in late July-early August, with last enlarging xylem cells observed on DOY $211 \pm 1.7$ days. Finally, last wallthickening cells were observed around mid-October (DOY $278 \pm 2.1$ days), marking the end of carbon deposition within the forming wood. The 2015 growing season (delimited by onset and cessation of cambial activity) lasted about $97 \pm 2.5$ days from late April to early August, while the whole process of wood formation (delimited by onset of cambial activity and cessation of wall-thickening cell) lasted up to $164 \pm 2.1$ days from late April to early October.

\subsection{Intra-annual dynamics of spruce growth in size and in biomass through cellular approach}

In the cellular approach, the intra-annual dynamics of xylem size increase (XSI) and aboveground woody biomass production (AWP) were characterized by highlighting the contribution of each cellular developmental process (cambial division, xylem cell enlargement and wall thickening). Daily XSI followed a bell-shaped curve (Fig. 3a). It started to increase in early April onward to peak in late May, then slowly decreased until cessation in early August. XSI resulted at nearly $80 \%$ from the contribution of enlarging xylem cells, while the remaining $20 \%$ was due to cell production through cambial division. Consequently, daily dynamics of XSI closely followed those of cell enlargement contribution along the growing season.

Intra-annual AWP dynamics followed a bell-shaped curve skewed to the right (Fig. 3b). AWP slowly started to increase in early April, essentially due to the contribution of

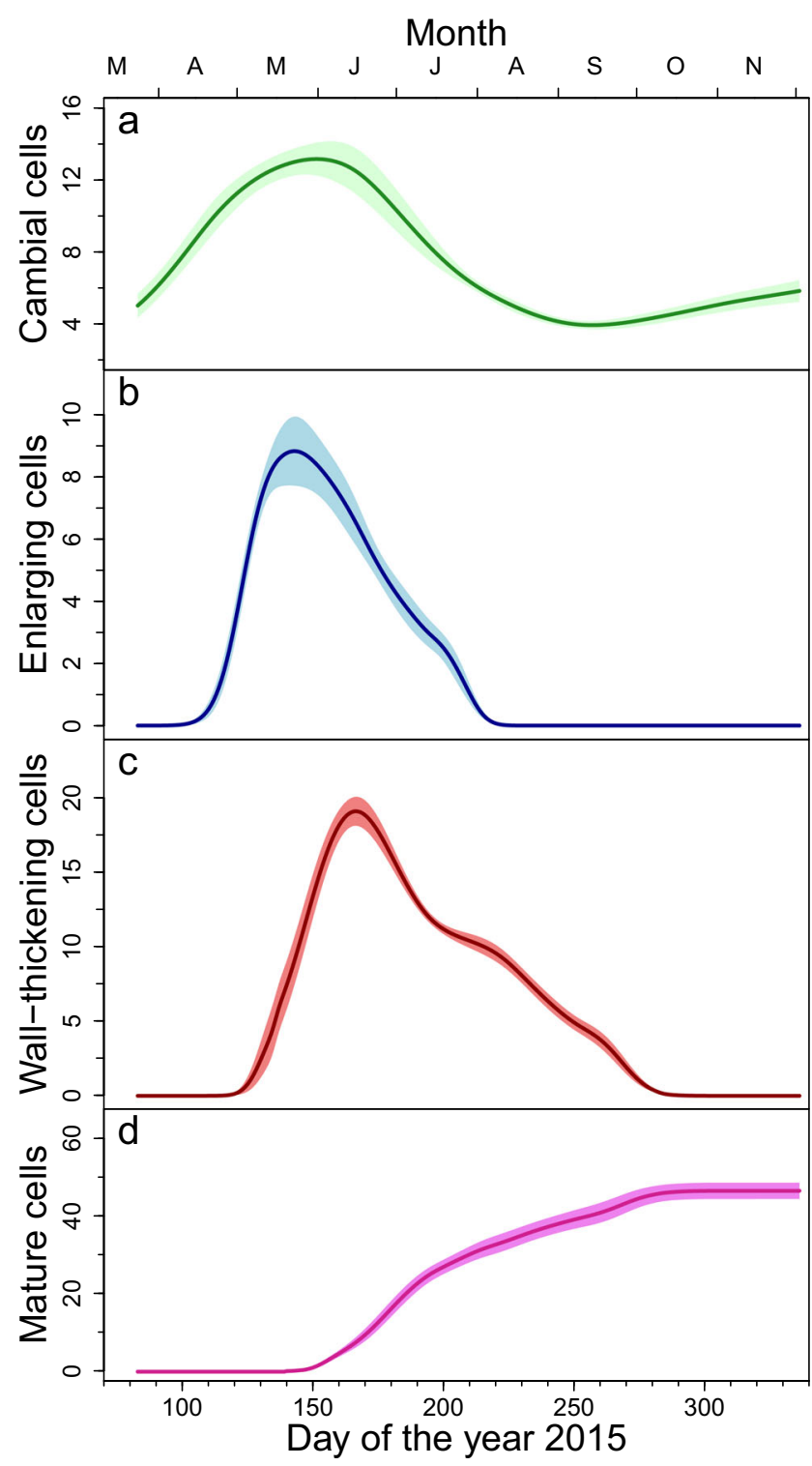

Fig. 2 Intra-annual dynamics of spruce wood formation during the 2015 growing season in Hesse. Generalized additive models (GAMs) fitted to the number of cells counted weekly in the cambial $\mathbf{a}$, enlargement $\mathbf{b}$, and wall-thickening $\mathbf{c}$ zones. Generalized additive model under shape constraints (SCAMs) fitted to the cells counted weekly in the mature $\mathbf{d}$ zone. The line represents the mean values for seven trees, and the shadowed area delimits the standard error

cambial cell production. It quickly increased in early May, due to the contribution of enlarging and wall-thickening xylem cells. Then AWP peaked on early to mid-June, quickly decreased until late July, and stagnated before returning to zero in mid-October. From late April to late June, wall thickening contributed at up to $85 \%$ to the AWP, while the production and enlargement of xylem cells both contributed to only $15 \%$. From late July to mid-October, seasonal dynamics of AWP mainly resulted from the maturation of the last differentiating xylem cells. 
Fig. 3 Intra-annual dynamics of xylem size increase and aboveground woody biomass production during the 2015 growing season assessed through the cellular approach. Rate of xylem size increase, with isolated contributions of cell production and cell enlargement. Rate of aboveground woody biomass production, which sums the carbon sequestered by wallthickening and enlarging xylem cells, and by the cell production through cambial division. Curves are mean for the seven spruce trees

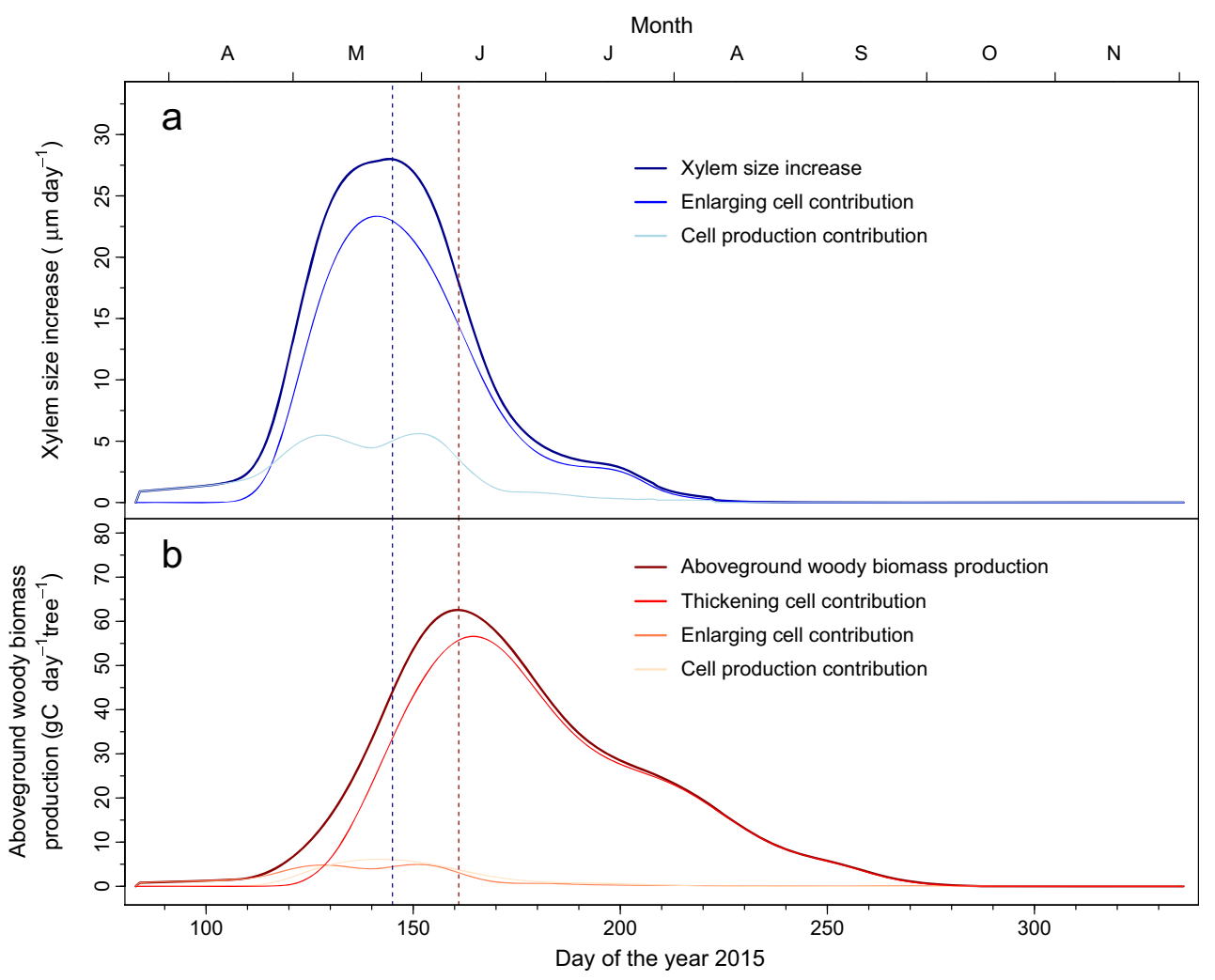

\subsection{Intra-annual dynamics of spruce growth in size and in biomass through histologic approach}

The seven monitored trees presented an average annual XRI of $1472 \pm 88 \mu \mathrm{m}$ (mean \pm standard error, Fig 4a, b). At intraannual scale, the cumulated XRI followed S-shape curves with slow starts from late April to mid-May, followed by a fast increase until late June, and finally a slowing down to cessation in early August. XAD slowly increased from April to early May (Fig. 4b), at the period when dividing cells started to be accumulated in the cambial zone, and first differentiating xylem cells were observed. Then, XAD quickly increased until early July, corresponding to the period of high xylem cell production, as differentiating and mature xylem cells became more abundant. Finally, XAD slowly increased, until stagnation in October-November, when the xylem was fully mature. The cumulated woody biomass production followed an S-shape curve (Fig. 4c), reaching a mean of 4.4 $\pm 0.3 \mathrm{kgC}$ tree $^{-1}$. It presented a slow start from late April to late May, followed by a quick increase until mid-June, and then again, a slow increase until stagnation in mid-October.

\subsection{Comparison of the cellular and histologic approaches}

Both the histologic and the cellular approaches allowed capturing the intra-annual dynamics of xylem size increase and aboveground woody biomass production with accuracy, presenting comparable seasonal patterns (Figs. 5, 6, and 7). The comparison of the cumulated XRI showed a maintained but not significant $100 \mu \mathrm{m}$ difference between the two approaches (TukeyHSD test, $P>0.05$ ). The radial growth assessed with the cellular approach ranged slightly below that assessed with the histologic one (Fig. 5a, b, c). When comparing the cumulated AWP, a not significant difference of around $0.8 \mathrm{kgC}$ tree $^{-1}$ was found in June-July, which dropped to less than $0.2 \mathrm{kgC}$ tree ${ }^{-1}$ toward the end of the growing season (TukeyHSD test, $P>0.05$ ). Biomass production assessed through cellular approach ranged slightly below that assessed through the histologic one (Fig. 6a, b, c).

Concerning the intra-annual rate of XRI, both approaches showed bell-shape curves, with a slightly more left-skewed one for the histologic approach (Fig. 7a). It appeared that the histologic approach advanced the cellular one, in late April for almost 10 days, with a quick increase reaching $10 \mu \mathrm{m}$ per day, followed by a short stagnation by early May. The radial increment assessed through the histologic approach quickly regrew onward and peaked around late May, 10 days behind that from the cellular approach. The same 10-day delay between the two methods was noted during the XRI decline occurred from midJune to August, which was followed by a stagnation in early to mid-August. Moreover, both approaches lead to similar bellshape curves for AWP (Fig. 7b), but with a maintained delay of 10 to 30 days between them. Indeed, the biomass production 


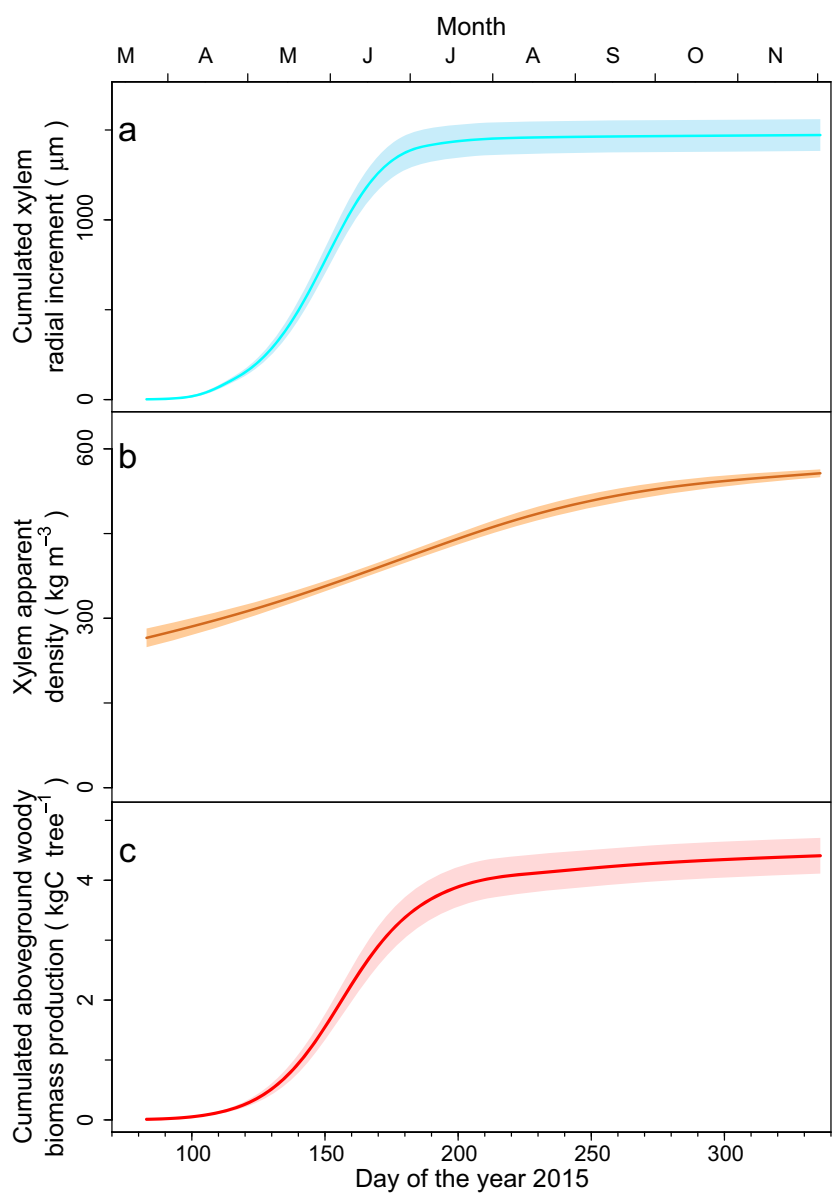

Fig. 4 The seasonal dynamics of the different variables measured through histologic approach. a The xylem radial increment, $\mathbf{b}$ the xylem apparent density, and $\mathbf{c}$ the aboveground woody biomass production. The line represents the mean of cumulated values for the seven spruce trees and the shadowed area represents the standard error assessed through histologic approach evolved always before the cellular one along the growing season. In mid-April, both approaches showed an increase in biomass production, but despite the curve for the histologic approach increased about 10 days ahead, maximum values occurred at similar dates, from early to mid-June (delay of less than 5 days). Finally, through the cellular approach, the daily rate of AWP started to decline from late June onward to stagnate at a very low level for 3 months (July to September), and returned to zero in midOctober. Through the histologic approach, AWP showed an abrupt decline from late June to August, always ahead AWP assessed through cellular approach, with a delay of 10 days in mid-July, extending up to 30 days in August.

\section{Discussion}

In this study, we presented a novel "histologic" approach to quantify the intra-annual dynamics of woody carbon sequestration based on anatomical section repeated measurements of developing xylem radial increment and apparent density. For more insights on the methods, we compared the novel "histologic" approach to the formerly published "cellular" approach (Cuny et al. 2015). We found that the two approaches provided comparable seasonal patterns of stem radial growth and woody biomass production but exhibited slightly different timings.

\subsection{Comparable results with the two cellular and histologic approaches}

We found that the two approaches lead to similar patterns of intra-annual stem radial growth. The histologic and cellular

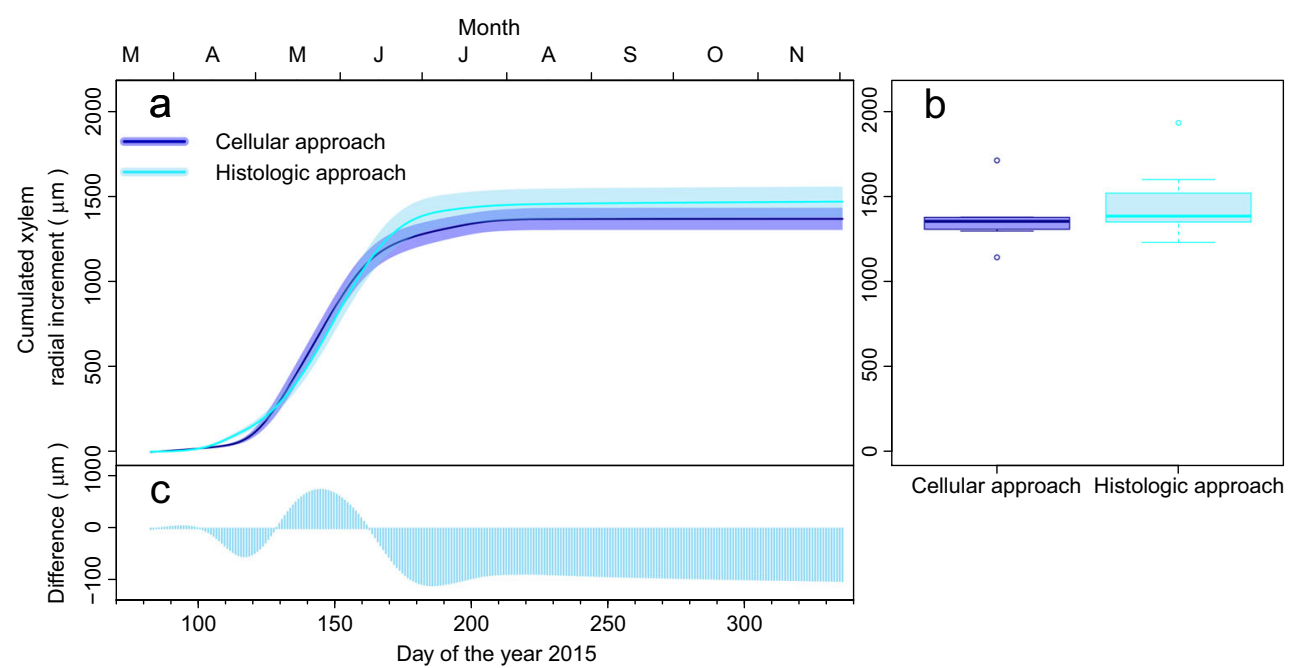

Fig. 5 Comparison of the cumulated growth in size through the cellular and histologic approaches. a Cumulated xylem size increase through the two approaches (the line represents the mean of cumulated values for the seven trees and the shadowed area represents the standard error). b Comparison of the final tree ring width calculated following the two approaches. $\mathbf{c}$ Bias for the estimation of growth in size between the two approaches (differences between each daily estimated value in $\mu \mathrm{m}$ ). For the difference, the blue vertical bars represent the mean daily values for seven trees 
Fig. 6 Comparison of the cumulated aboveground woody biomass through the cellular and histologic approaches. a Cumulated aboveground woody biomass production. $\mathbf{b}$ Comparison of the total aboveground woody biomass produced calculated following the two approaches. $\mathbf{c}$ Bias for the estimation of growth in biomass between the two approaches (differences between each daily estimated value in $\mathrm{kg} \mathrm{C}$ by tree). For the difference, the red vertical bars represent the mean daily values for seven trees

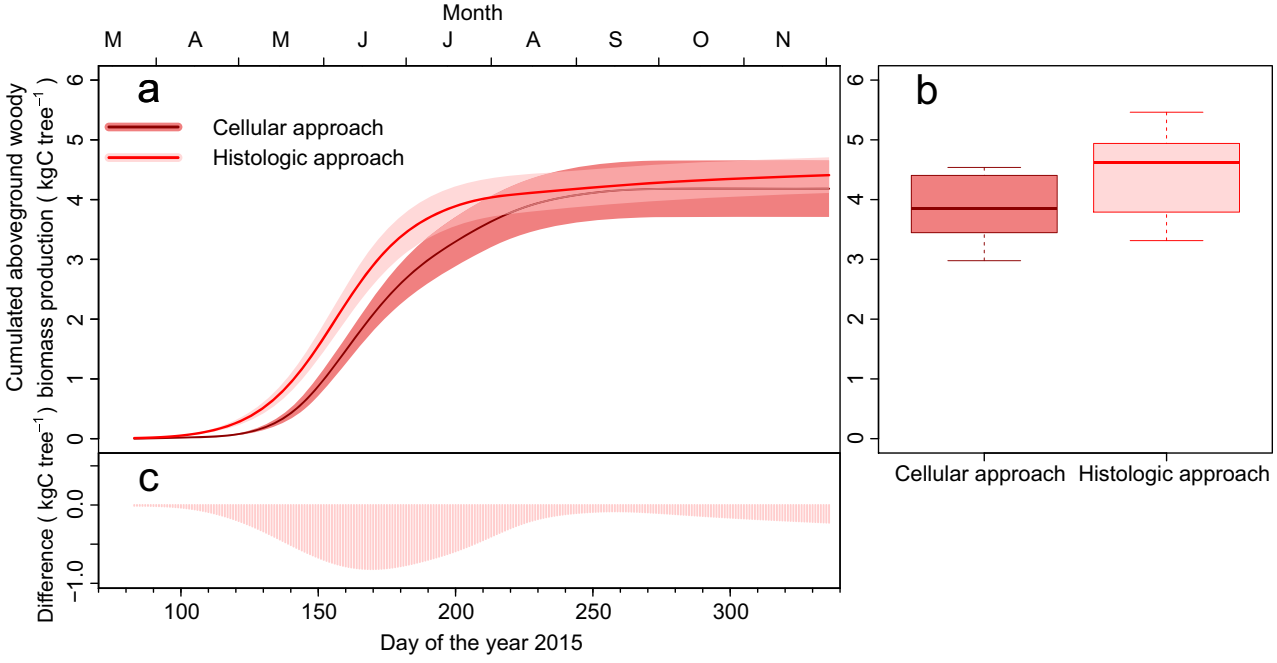

approaches estimated not significantly different tree ring widths. In the latter, data analysis aimed to overcome the anisotropy when rotating around the stem for microcore sampling and better characterize intra-annual dynamics of stem radial growth (Rathgeber et al. 2018). This suggests that data manipulation to characterize the kinetics of wood formation (e.g., determination of a median ring cell number at the end of the growing season, and the computation of the total number of cells in the stem cross area) tends to underestimate the total amount of tracheids produced at the end of the growing season. The quick stem radial increase obtained from late April to early May by the histologic approach could be attributed to rapid cell division, which lead xylem mother cells to be accumulated in the cambial zone. Newly produced cells at this period could have differentiated in higher proportion at the phloem side than at the xylem (Gričar and Čufar 2008; Jyske et al. 2014; Gričar et al. 2015), explaining the short stagnation noted in early May through the histologic approach. With the cellular approach, we equally distributed the processes along time, attributing the same daily rate of
Fig. 7 Comparison of the intraannual dynamics of growth in size and in biomass through the cellular and histologic approaches. a Xylem size increase and $\mathbf{b}$ Aboveground woody biomass production

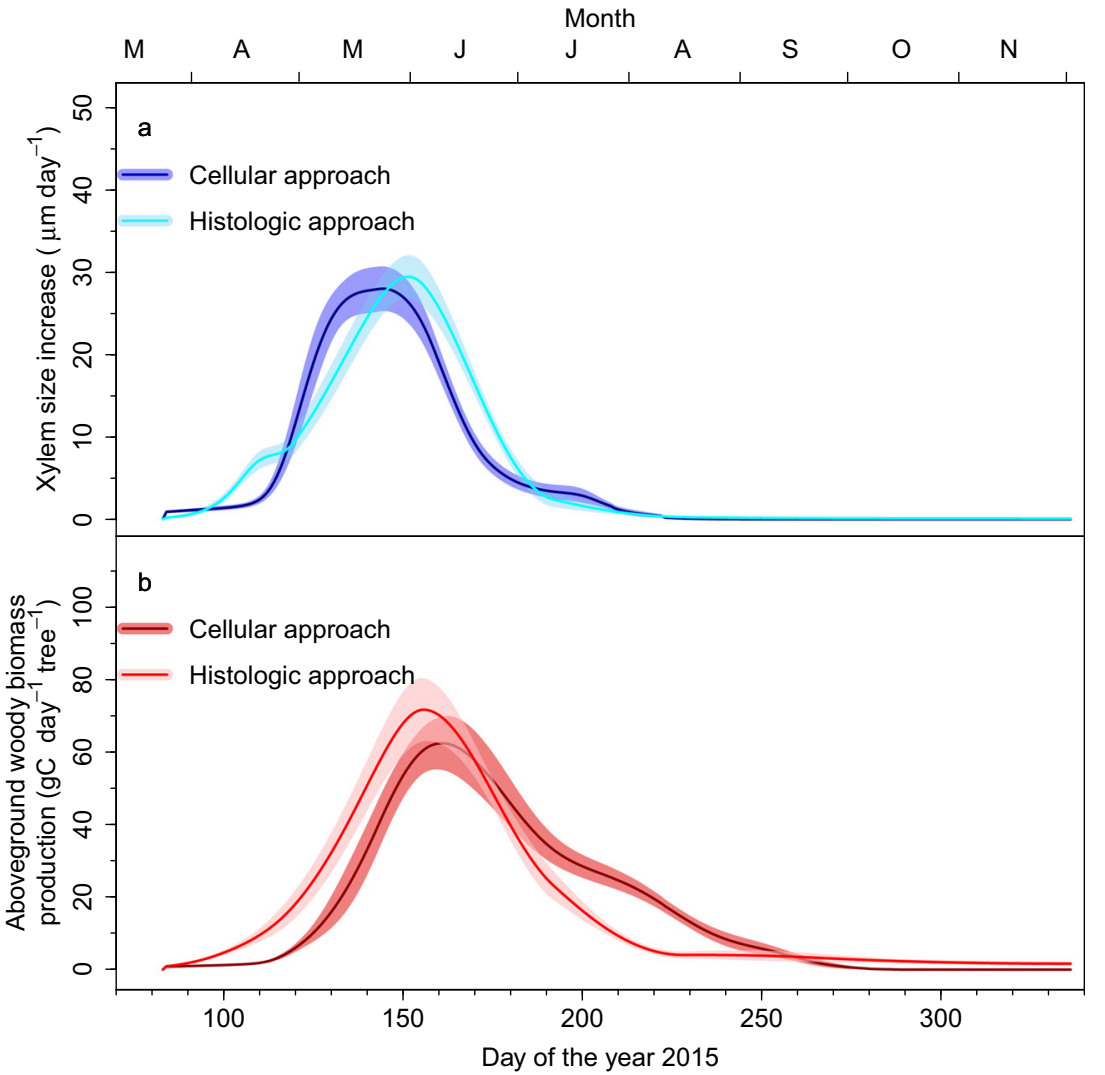


radial expansion along the whole cell enlargement period, explaining also the large plateau in July-August toward the end of the growing season. However, computation of xylogenesis kinetics through the cellular approach permitted us to disentangle cambial division and cell enlargement contribution at very fine scale. We showed a transient contribution of cambial cell division in early May, slowing down in late May, leading to a plateau for stem radial increment, onward to peak between late May and early June.

The total biomass produced assessed through the two approaches ranged at similar levels. Concerning the shape of the patterns along the growing season, the daily rates of aboveground woody biomass from the cellular and the histologic approaches followed parallel bell-shaped curves, the one assessed through the histologic approach always ahead the other one. The shift between the two curves could be explained by the different assumption of rates of carbon deposition on which the two approaches relied. Since we considered changes in cell wall thickness but not in lignification, the histologic approach tended to anticipate the completion of each tracheid maturation, and then the gain in mass of the forming xylem. Thus, it would be desirable to quantify the contribution of lignification, which could continue longer after completion of secondary wall deposition, and which could be probably achieved by using confocal microscopy (Donaldson 2013; Dickson et al. 2016). The histologic approach also overestimated cell wall proportion because cell lumen content could not be completely removed from the images, although it represented less than $5 \%$ of the measured cell wall proportion (pers. obs.). However, developing more advanced image processing tools is recommended in the future for a more accurate estimation of woody biomass production. On the other hand, despite the cellular approach is able to estimate the timing of wall-thickening for each cell, it assumes that the final amount of cell wall is equally distributed during the whole deposition period (Cuny et al. 2014, 2015). Consideration of a constant wall deposition rate could have slowed down rates of biomass production throughout the growing season.

\subsection{A particular dry 2015 growing season for our study case on spruce}

In our study, xylem size increase followed a unimodal pattern, peaking in May, and leading to nearly 50 total tracheids produced. It differed from the bimodal pattern peaking in May and to a less extend in early July as previously reported for spruce and other conifers in north-eastern France (Cuny et al. 2015), and reaching nearly 75 total tracheids produced. We also found a narrower bell-shaped curve of daily woody biomass production with an earlier slowing down in July-August and stopping in mid-October, while biomass production followed a large and symmetric bell-shaped curve peaking in early July, and dropping to zero in November (Cuny et al. 2015). In addition, the 2 -week time lag between stem growth in size and in biomass observed in our study contrasted with the 1-month delay reported by Cuny et al. (2015). These results could have been partially accounted for a particularly long summer drought in 2015, which probably shortened the growing season length and reduced tracheid production. Indeed, we noted an earlier cessation of cambial activity (early August) than in previous studies for Norway spruce, with last enlarging xylem cells observed between late August and early September (Jyske et al. 2014; Cuny et al. 2015). In addition, mature xylem at the time of cessation of cambial activity was almost exclusively composed by earlywood cells, comprising more than $50 \%$ of the total produced cells. This could indicate a lower density due to higher earlywood-to-latewood proportion (Cuny et al. 2014). These results suggest that wood formation in Norway spruce is highly sensitive to drought events occurring under temperate conditions. A shorter growing season and narrower latewood may reduce carbon allocation to cell wall formation. Reduction of carbon investment in growth is a common response to stress, which may allow trees to mobilize carbon for osmotic purposes (Deslauriers et al. 2014), instead of producing more cells, which will require to invest carbon in the wall of these newly produced xylem cells. This is the case for conifers in boreal and temperate forests (Balducci et al. 2015; Martin et al. 2017), conifers in Mediterranean forests (Novak et al. 2016; Fernández-de-Uña et al. 2017; Balzano et al. 2018), or angiosperms and conifer in tropical forests (Trouet et al. 2012; Mitchell et al. 2014; Van Camp et al. 2018). However, such a xylem growth adjustment to drought may have limited effects if more stressful conditions prompt irreversible deterioration of the hydraulic system (Cailleret et al. 2017). Therefore, under scenarios of increasing recurrence of drought episodes, our study constrained to 1 year and one species could not allow further interpretation. But it highlights the need of long-term monitoring to better understand how the climate modulates tree ring width and density (Rathgeber 2017; Björklund et al. 2017), and the consequent dynamics of stem radial growth and carbon sequestration.

\section{Conclusion}

In this study, we developed a novel, simple, and direct approach to quantify the intra-annual dynamics of carbon sequestration in the forming wood, based on repeated measurements on histological sections of apparent density and radial increment of forming xylem. We showed that the histologic approach provided comparable patterns of stem growth in size and in biomass, compared with the formerly 
published cellular approach, which was based on detailed assessment of the kinetics of tracheid differentiation. Both approaches lead to similar bell-shaped curves of xylem size increase and aboveground woody biomass production, culminating respectively in May and June. Yet, due to different assumption of wall deposition kinetics within each approach, the time lag assessed between stem growth in size and in biomass was shorter for the histologic approach than for the cellular one. The histologic approach is easily applicable to angiosperm species exhibiting heterogeneous anatomical structures and diversity of cell types, opening perspectives to characterize for the first time the intra-annual dynamics of carbon sequestration for these species.

Acknowledgments The authors would like to thank SILVATECH from INRA Grand-Est Nancy research center, especially E. Cornu and P. Gelhaye for monitoring work on the field, M. Harroué and A. Motz for sample preparation in the laboratory. This article forms a part of the $\mathrm{PhD}$ dissertation of Anjy N. Andrianantenaina.

Author's contribution Supervision: CBKR; Funding acquisition: CBKR, AA; Experimental design: CBK; Data acquisition: AA, JR, CBKR; Data analysis: AA, CBKR; First draft: AA, CBKR; Final writing: AA, CBKR, GPDL, HC, JR.

Funding information This work was supported by a grant overseen by the French National Research Agency (ANR) as part of the "Investissements d'Avenir" program (ANR-11-LABX-0002-01, Lab of Excellence ARBRE), and by the National Institute of Agricultural Research (INRA Grand-Est Nancy) with a doctoral fellowship granted to the first author (CJS, "Contrat Jeune Scientifique").

Data availability The datasets generated and/or analyzed during the current study are available in the Portail Data INRA repository (Andrianantenaina et al. 2019) at https://doi.org/10.15454/PINS1H.

\section{Compliance with ethical standards}

Conflicts of interest The authors declare that they have no conflict of interest.

\section{Annex 1 Computation of the critical dates for the different xylogenesis phenophases based on cell-counting dataset, and on binary notation}

The aim is to develop a methodology to determine the phenology of wood formation, with comparable approach for the Norway spruce specie. We aimed to determine five critical dates and three durations from cell-counting dataset and anatomical observations for Norway spruce, using logistic regressions (Rathgeber et al. 2018). These critical dates correspond to the onset of enlarging (bE), wall-thickening and lignification (bW) and mature phases $(\mathrm{bM})$, and the cessation of enlarging $(\mathrm{cE})$, wall-thickening and lignification $(\mathrm{cW})$. The onset and cessation were defined respectively as the dates at which $50 \%$ of the radial files were active (onset) or non-active (cessation).
Cell counting and anatomical observations were performed on each anatomical slide. For anatomical observations, binary notations were performed. The slide was first divided in three equal zones, then a binary notation was performed for each zone: 1 or 0 respectively for presence or absence of enlarging, maturing or mature cells. The duration of enlarging (dE), wall-thickening and lignification $(\mathrm{dW})$ phases were the time between the onset and cessation of these phases. The duration of xylogenesis $(\mathrm{dX})$ was the time between $\mathrm{bE}$ and $\mathrm{cW}$.

Finally, we compared the dates determined through the two approaches: cell-counting and binary notation using a function in CAVIAR (Rathgeber et al. 2018). For each xylogenesis phenophases, the mean critical dates and duration are illustrated in Fig. S2, and the values for each tree in Table S4.

\section{Annex 2 The anatomical criteria to differentiate dormant and dividing cambial cells}

The different anatomical criteria described are based on the following studies: Chaffey et al. 1998; Prislan et al. 2011, 2016; Michelot et al. 2012; Schmitt et al. 2013, 2016

\begin{tabular}{cc}
\hline & Anatomical criteria \\
\hline $\begin{array}{c}\text { Dormant } \\
\text { cambial zone }\end{array}$ & $\begin{array}{c}\text { Cambial zone composed of } 3 \text { to } 4 \text { layers } \\
\text { of cambial cells } \\
\text { - Observation of flat and ordered cambial cells } \\
\text { - Cambial cells with thick primary wall } \\
\text { - }\end{array}$ \\
& Gross transition with the boundary of the xylem ring \\
& an advanced stage of wall-thickening phase) \\
Active cambial & Increase of the number of dividing cells in the \\
zone & cambial zone with appearance of new cell plates, \\
& and formation of several radial layers of cambial \\
& cells \\
& Dividing cells with doubling and thin cell wall, and \\
& with disturbance in the cambial zone \\
& Progressive transition from cambial zone to the inner \\
& side of the xylem ring (juxtaposition with enlarging \\
& xylem cells)
\end{tabular}

\section{Annex 3 Description of the allometric equation to compute the aboveground woody biomass production by tree using the histologic approach}

Aboveground woody biomass production was calculated for each tree using the equations established by (Vallet et al. 2006). A form coefficient (Fi) was computed to integrate the form of the stem for spruce species. 
$F i=$ form $(C B H, H)$

$$
=(\alpha+\beta \cdot \mathrm{CBH}+\gamma \cdot \mathrm{hdn})\left(1+\frac{\delta}{C B H^{2}}\right)
$$

with $h d n=\frac{C 130^{1 / 2}}{H}$ and the different parameters to compute the form coefficient:

$$
\alpha=0.631 ; \beta=-0.000946 ; \gamma=0 ; \delta=0
$$

\section{References}

Abe H, Funada R, Ohtani J, Fukazawa K (1997) Changes in the arrangement of cellulose microfibrils associated with the cessation of cell expansion in tracheids. Trees 11:328-332

Abramoff MD, Magalhaes PJ, Ram SJ (2004) Image Processing with Image. J Biophotonics Int 11:36-42

Andrianantenaina AN, Rathgeber CBK, Pérez-de-Lis G, Cuny H, Ruelle J (2019) A novel histologic approach to quantify the intra-annual dynamics of carbon sequestration in spruce forming wood. V1. Portail Data Inra. [Dataset]. https://doi.org/10.15454/PINS1H

Balducci L, Deslauriers A, Giovannelli A, Beaulieu M, Delzon S, Rossi S, Rathgeber CBK (2015) How do drought and warming influence survival and wood traits of Picea mariana saplings? J Exp Bot 66: 377-389. https://doi.org/10.1093/jxb/eru431

Balzano A, Čufar K, Battipaglia G, Merela M, Prislan P, Aronne G, de Micco V (2018) Xylogenesis reveals the genesis and ecological signal of IADFs in Pinus pinea L. and Arbutus unedo L. Ann Bot 121:1231-1242. https://doi.org/10.1093/aob/mcy008

Barnett J, Jeronimidis G (2009) Wood quality and its biological basis. John Wiley \& Sons

Björklund J, Seftigen K, Schweingruber F, Fonti P, von Arx G, Bryukhanova MV, Cuny HE, Carrer M, Castagneri D, Frank DC (2017) Cell size and wall dimensions drive distinct variability of earlywood and latewood density in northern hemisphere conifers. New Phytol 216:728-740. https://doi.org/10.1111/nph.14639

Bonan GB (2008) Forests and climate change: forcings, feedbacks, and the climate benefits of forests. Science 320:1444-1449

Bouriaud O, Teodosiu M, Kirdyanov AV, Wirth C (2015) Influence of wood density in tree-ring-based annual productivity assessments and its errors in Norway spruce. Biogeosciences 12:6205-6217. https://doi.org/10.5194/bg-12-6205-2015

Cailleret M, Jansen S, Robert EMR, Desoto L, Aakala T, Antos JA, Beikircher B, Bigler C, Bugmann H, Caccianiga M, Čada V, Camarero JJ, Cherubini P, Cochard H, Coyea MR, Čufar K, Das AJ, Davi H, Delzon S, Dorman M, Gea-Izquierdo G, Gillner S, Haavik LJ, Hartmann H, Hereş AM, Hultine KR, Janda P, Kane JM, Kharuk VI, Kitzberger T, Klein T, Kramer K, Lens F, Levanic T, Linares Calderon JC, Lloret F, Lobo-Do-Vale R, Lombardi F, López Rodríguez R, Mäkinen H, Mayr S, Mészáros I, Metsaranta JM, Minunno F, Oberhuber W, Papadopoulos A, Peltoniemi M, Petritan AM, Rohner B, Sangüesa-Barreda G, Sarris D, Smith JM, Stan AB, Sterck F, Stojanović DB, Suarez ML, Svoboda M, Tognetti R, Torres-Ruiz JM, Trotsiuk V, Villalba R, Vodde F, Westwood AR, Wyckoff PH, Zafirov N, Martínez-Vilalta J (2017) A synthesis of radial growth patterns preceding tree mortality. Glob Chang Biol 23:1675-1690. https://doi.org/10.1111/gcb.13535

Chaffey NJ, Barlow PW, Barnett JR (1998) A seasonal cycle of cell wall structure is accompanied by a cyclical rearrangement of cortical microtubules in fusiform cambial cells within taproots of Aesculus hippocastanum (Hippocastanaceae). New Phytol 139:623-635. https://doi.org/10.1046/j.1469-8137.1998.00241.x

Chave J, Muller-Landau HC, Baker TR et al (2006) Regional and phylogenetic variation of wood density across 2456 neotropical tree species. Ecol Appl 16:2356-2367

Cuny HE, Rathgeber CBK, Frank D, Fonti P, Fournier M (2014) Kinetics of tracheid development explain conifer tree-ring structure. New Phytol 203:1231-1241. https://doi.org/10.1111/nph.12871

Cuny HE, Rathgeber CBK, Frank D, Fonti P, Mäkinen H, Prislan P, Rossi $\mathrm{S}$, del Castillo EM, Campelo F, Vavrčík H, Camarero JJ, Bryukhanova MV, Jyske T, Gričar J, Gryc V, de Luis M, Vieira J, Čufar K, Kirdyanov AV, Oberhuber W, Treml V, Huang JG, Li X, Swidrak I, Deslauriers A, Liang E, Nöjd P, Gruber A, Nabais C, Morin H, Krause C, King G, Fournier M (2015) Woody biomass production lags stem-girth increase by over one month in coniferous forests. Nat Plants 1:15160. https://doi.org/10.1038/nplants.2015. 160

Cuny HE, Rathgeber CBK, Kiesse TS et al (2013) Generalized additive models reveal the intrinsic complexity of wood formation dynamics. J Exp Bot 64:1983-1994. https://doi.org/10.1093/jxb/ert057

Deslauriers A, Beaulieu M, Balducci L, Giovannelli A, Gagnon MJ, Rossi S (2014) Impact of warming and drought on carbon balance related to wood formation in black spruce. Ann Bot 114:335-345. https://doi.org/10.1093/aob/mcu111

Dickson A, Nanayakkara B, Sellier D, Meason D, Donaldson L, Brownlie R (2016) Fluorescence imaging of cambial zones to study wood formation in Pinus radiata D. Don Trees 31:479-490. https:// doi.org/10.1007/s00468-016-1469-3

Donaldson L (2013) Softwood and hardwood lignin fluorescence spectra of wood cell walls in different mounting media. IAWA J 34:3-19. https://doi.org/10.1163/22941932-00000002

Donaldson LA (2001) Lignification and lignin topochemistry - an ultrastructural view. Phytochemistry 57:859-873

Fernández-de-Uña L, Rossi S, Aranda I, Fonti P, González-González BD, Cañellas I, Gea-Izquierdo G (2017) Xylem and leaf functional adjustments to drought in Pinus sylvestris and Quercus pyrenaica at their elevational boundary. Front Plant Sci 8:1200. https://doi.org/ 10.3389/fpls.2017.01200

Granier A, Bréda N, Biron P, Villette S (1999) A lumped water balance model to evaluate duration and intensity of drought constraints in forest stands. Ecol Model 116:269-283

Gričar J, Čufar K (2008) Seasonal dynamics of phloem and xylem formation in silver fir and Norway spruce as affected by drought. Russ J Plant Physiol 55:538-543. https://doi.org/10.1134/ S102144370804016X

Gričar J, Prislan P, de Luis M, Gryc V, Hacurová J, Vavrčík H, Čufar K (2015) Plasticity in variation of xylem and phloem cell characteristics of Norway spruce under different local conditions. Front Plant Sci 6:730. https://doi.org/10.3389/fpls.2015.00730

Harroué M, Cornu E, Rathgeber C (2011) Méthodes de prélèvement et de préparation des échantillons pour l'étude de l'activité cambiale et de la formation du bois. Cah Tech INRA 73:45-62

Heid L, Calvaruso C, Andrianantenaina A et al (2018) Seasonal timecourse of the above ground biomass production efficiency in beech trees (Fagus sylvatica L.). Ann For Sci 75:31

Jyske T, Mäkinen H, Kalliokoski T, Nöjd P (2014) Intra-annual tracheid production of Norway spruce and scots pine across a latitudinal gradient in Finland. Agric For Meteorol 194:241-254. https://doi. org/10.1016/j.agrformet.2014.04.015

Kagawa A, Sugimoto A, Yamashita K, Abe H (2005) Temporal photosynthetic carbon isotope signatures revealed in a tree ring through 13CO2 pulse-labelling. Plant Cell Environ 28:906-915

Kraenzel M, Castillo A, Moore T, Potvin C (2003) Carbon storage of harvest-age teak (Tectona grandis) plantations, Panama. For Ecol Manag 173:213-225. https://doi.org/10.1016/S0378-1127(02) 00002-6 
Lamlom SH, Savidge RA (2003) A reassessment of carbon content in wood: variation within and between 41 north American species. Biomass Bioenergy 25:381-388. https://doi.org/10.1016/S09619534(03)00033-3

Lundqvist S-O, Seifert S, Grahn T, Olsson L, García-Gil MR, Karlsson B, Seifert T (2018) Age and weather effects on between and within ring variations of number, width and coarseness of tracheids and radial growth of young Norway spruce. Eur J For Res 137:719-743. https://doi.org/10.1007/s10342-018-1136-x

Martin J, Nathaniel L, Zachary H et al (2017) Hydrometeorology organizes intra-annual patterns of tree growth across time, space and species in a montane watershed. New Phytol 215:1387-1398. https://doi.org/10.1111/nph.14668

Mellerowicz EJ, Baucher M, Sundberg B, Boerjan W (2001) Unravelling cell wall formation in the woody dicot stem. Plant Mol Biol 47:239274

Michelot A, Simard S, Rathgeber C, Dufrene E, Damesin C (2012) Comparing the intra-annual wood formation of three European species (Fagus sylvatica, Quercus petraea and Pinus sylvestris) as related to leaf phenology and non-structural carbohydrate dynamics. Tree Physiol 32:1033-1045. https://doi.org/10.1093/treephys/ tps052

Mitchell PJ, O'Grady AP, Tissue DT et al (2014) Co-ordination of growth, gas exchange and hydraulics define the carbon safety margin in tree species with contrasting drought strategies. Tree Physiol 34:443-458. https://doi.org/10.1093/treephys/tpu014

Nabais C, Hansen JK, David-Schwartz R, Klisz M, López R, Rozenberg $P$ (2018) The effect of climate on wood density: what provenance trials tell us? For Ecol Manag 408:148-156. https://doi.org/10.1016/ j.foreco.2017.10.040

Novak K, de Luis M, Saz MA, Longares LA, Serrano-Notivoli R, Raventós J, Čufar K, Gričar J, di Filippo A, Piovesan G, Rathgeber CBK, Papadopoulos A, Smith KT (2016) Missing rings in Pinus halepensis - the missing link to relate the tree-ring record to extreme climatic events. Front Plant Sci 7:727. https://doi.org/10. $3389 /$ fpls.2016.00727

Popkin G (2015) Weighing the world's trees. Nature 523:20-22

Prislan P, Gričar J, de Luis M, Novak K, Martinez del Castillo E, Schmitt U, Koch G, Štrus J, Mrak P, Žnidarič MT, Čufar K (2016) Annual cambial rhythm in Pinus halepensis and Pinus sylvestris as Indicator for climate adaptation. Front Plant Sci 7:1923. https://doi.org/10. 3389/fpls.2016.01923

Prislan P, Schmitt U, Koch G, Gričar J, Čufar K (2011) Seasonal ultrastructural changes in the cambial zone of beech (Fagus sylvatica) grown at two different altitudes. IAWA J 32:443-459

Pya N, Wood SN (2015) Shape constrained additive models. Stat Comput 25:543-559. https://doi.org/10.1007/s11222-013-9448-7

Rathgeber CBK (2017) Conifer tree-ring density inter-annual variability anatomical, physiological and environmental determinants. New Phytol 216:621-625. https://doi.org/10.1111/nph.14763

Rathgeber CBK, Cuny HE, Fonti P (2016) Biological basis of tree-ring formation: a crash course. Front Plant Sci 7:734. https://oi.org/10. 3389/fpls.2016.00734
Rathgeber CBK, Santenoise P, Cuny HE (2018) CAVIAR: an R package for checking, displaying and processing wood-formationmonitoring data. Tree Physiol 38:1246-1260. https://doi.org/10. 1093/treephys/tpy054

Rossi S, Anfodillo T, Menardi R (2006) Trephor: a new tool for sampling microcores from tree stems. IAWA J 27:89-97

Sachsse H (1984) On the determination of wood density by microscopic linear-analysis. Holz Roh Werkst 42:121-129

Schmitt U, Koch G, Eckstein D, Seo J.W., Prislan P., Gričar J., Čufar K., Stobbe H., Jalkanen R. (2016) The vascular cambium of trees and its involvement in defining xylem anatomy. In: Secondary xylem biology. Elsevier, pp 3-24

Schmitt U, Koch G, Gričar J et al (2013) Review of cellular and subcellular changes in the cambium. IAWA J 34:391-407. https://doi.org/ $10.1163 / 22941932-00000032$

Seo YO, Lumbres RIC, Lee YJ (2012) Partitioning of above and belowground biomass and allometry in the two stand age classes of Pinus rigida in South Korea. Life Sci J 9:3553-3559

Thomas D, Montagu K, Conroy J (2004) Changes in wood density of Eucalyptus camaldulensis due to temperature - the physiological link between water viscosity and wood anatomy. For Ecol Manag 193:157-165. https://doi.org/10.1016/j.foreco.2004.01.028

Tolivia D, Tolivia J (1987) Fasga: a new polychromatic method for simultaneous and differential staining of plant tissues. J Microsc 148: $113-117$

Trouet V, Mukelabai M, Verheyden A, Beeckman H (2012) Cambial growth season of Brevi-deciduous Brachystegia spiciformis trees from South Central Africa restricted to less than four months. PLoS One 7:e47364. https://doi.org/10.1371/journal.pone.0047364

Vaganov EA (1990) The tracheidogram method in tree-ring analysis and its application. In: Cook ER, Kairiuktis LA (eds) Methods of dendrochronology: application in the environmental sciences. Kluwer Academic, Dordrecht, the Netherlands, pp 63-76

Vaganov EA, Hughes MK, Shashkin AV (2006) Growth Dynamics of Conifer Tree Rings. Springer-Verlag, Berlin/Heidelberg

Vallet P, Dhôte J-F, Moguédec GL, Ravart M, Pignard G (2006) Development of total aboveground volume equations for seven important forest tree species in France. For Ecol Manag 229:98-110. https://doi.org/10.1016/j.foreco.2006.03.013

Van Camp J, Hubeau M, Van den Bulcke J et al (2018) Cambial pinning relates wood anatomy to ecophysiology in the African tropical tree Maesopsis eminii. Tree Physiol 38:232-242. https://doi.org/10. 1093/treephys/tpx 151

Wood SN (2006) Generalized additive models - an introduction with R, Taylor \& Francis Group, LLC. Chapman \& Hall/CRC - Texts in Statistical Science Series

Publisher's note Springer Nature remains neutral with regard to jurisdictional claims in published maps and institutional affiliations. 